(RESEARCH ARTICLE)

\title{
Survey of fungal foliar diseases of Terminalia catappa in Usmanu Danfodiyo University Sokoto Northwestern Nigeria
}

\author{
Nasiru AM ${ }^{1, *}$, Sarki MA ${ }^{1}$ and Dalhatu MH ${ }^{2}$ \\ ${ }^{1}$ Department of Forestry \& Environment, Usmanu Danfodiyo University, Sokoto Nigeria. \\ 2 Department of Microbiology, Usmanu Danfodiyo University, Sokoto Nigeria.
}

Publication history: Received on 09 April 2020; revised on 30 May 2020; accepted on 02 June 2020

Article DOI: https://doi.org/10.30574/wjarr.2020.6.3.0094

\begin{abstract}
A survey on Fungal Foliar Diseases of Terminalia catappa in Usmanu Danfodiyo University Sokoto main campus was conducted to determine the causal organism responsible for the diseases, and its intensity in terms of incidence and severity. Incidence and severity were determined using disease rating scale, whereas pathogen responsible for the diseases were identified by taking the samples of infected leaves to mycology laboratory and cultured on Potato Dextrose Agar (PDA). Aspergillus Leaf Spot, Aspergillus Blight, and Black Mould all caused by Aspergillus species, as well as powdery mildew were found to be prevalent foliar diseases in the study area. Aspergillus Leaf spot recorded highest intensity in both incidence and severity in all the three (3) locations with $(96.67 \%, 100 \%$, and $69.84 \%)$ and (53.17\%, 62.20\% and 15.87) respectively, followed by Aspergillus Blight with incidence (78.55\%, 95.24\% and 53.97\%) and severity of $(12.65 \%, 11.14 \%$ and $7.30 \%)$, Black Mould disease recorded the incidence of $(73.89 \%, 94.96 \%$ and $59.52 \%)$ and severity of $(14.27 \%, 16.86 \%$ and $13.36 \%)$. Powdery mildew showed the least incidence of $(58.53 \%, 85.71 \%$ and $15.08 \%)$ and severity $(9.65 \%, 34 \%$ and $3.89 \%)$ in the respective locations. The diseases occurs as a result of infection from a cosmopolitan fungus species (Aspergillus) and the high intensity was as a result of high humidity coupled with closed spacing, hence favoring the proliferation of the pathogen. The study recommended that silvicultural practices like pruning for good air circulation, sanitary practices like getting rid of the infected fallen leaves and dead twigs, as well as minimizing stress to keep the trees healthy should be practiced to limit the infection and reduces the menace of the diseases.
\end{abstract}

Keywords: Terminalia catappa; Pathogens; Aspergillus; Blight; Disease; Incidence and Severity

\section{Introduction}

The species Terminalia catappa belongs to the family Combretaceae in the wood leading and pantropical genus "Terminalia" which comprises of about 150 species; the key references to this genus include Exel [1], Coode [2] and Smith [3]. Its generic name "Terminalia" was derived from the characteristic clustered spiral of leaves at the twigs tips, the specific epithet "Catappa" was taken from its name in Malaysia; viz. "Catapang" [4]. The plant is originally from Africa, Asia, and Australia before spreading to other part of the world, it is a hardy, fast growing, deciduous, multipurpose tree with upright and tall trunk bearing horizontal branches that are mostly arrange in tiers reaching 25(40) $\mathrm{m}$ tall, under suitable condition, it is well formed tree that has been widely planted throughout the tropics for shade, ornament, and nuts especially along sandy coastal shores [5].

The species however suffers or may be affected by different diseases ranging from those that cause only aesthetic problems which cause no long term damage to the tree to those that seriously disfigure, significant and sometimes disconcerting premature leaf drop [6]. Such diseases are a serious hurdle to the multitude number of products and services realized from the Tropical almond.

\footnotetext{
${ }^{*}$ Corresponding author: Nasiru AM
} 
Despite the fact that Terminalia catappa provides valuable products and quite number of services to the man and his ecosystem, its productivity is limited or affected by different diseases. According to Douglas [6], leaf diseases are probably the most common diseases affecting such species much of which are caused by fungi, although other organisms such as bacteria and nematodes can also cause foliar diseases in such species; some of the fungi associated with leaf spot are: Alternaria, Aschochyta, Blumeriella, Cercospora, Colletotrichum, Entomosporium, Gnomonia, Guignardia, Mycosphaerella, Phyllosticta, Septoria, Tubakia, and Venturia among others. Terminalia catappa is of significant importance as majority of the work so far done on the species inclined more on its medicinal value, little was done on the pests and diseases that threatened the reproductive potentials of the species.

The main aim is to identify the foliar diseases of Terminalia catappa and measure the level or intensity of the diseases in the study area.

\section{Material and methods}

\subsection{Study Area}

The research was carried out at Usmanu Danfodiyo University Sokoto permanent site in Wamakko Local Government Area of Sokoto State in north-western Nigeria. Located between latitude $11.6^{0} \mathrm{~N}-13.9^{\circ} \mathrm{N}$ and longitude $3.7^{\circ} \mathrm{E}-6.9^{\circ} \mathrm{E}$ [7].

The area falls under Sudan savanna zone characterized by two distinct seasons (wet and dry) of varying duration and intensity [8]. The rainy season is often 3-4 month (usually from May to September) with the highest rainfall in August, the mean annual rainfall $500-750 \mathrm{~mm}$ with, relatively high temperature though it varies with season [8]. The mean annual temperature is $34.5^{\circ} \mathrm{C}$ with dry season temperatures exceeding $40^{\circ} \mathrm{C}$ [9]. The vegetation zone which is characterized by few scattered trees among dominating herbaceous layer, shrubs, which are threatened by inhabitants as a result of over exploitation without replacement; in addition, temperature, rainfall, and wind are the main climatic factors that are aggravating lack of vegetation in the area [8].

\subsection{Sampling Technique}

Purposive sampling was employed to sample out the diseased trees in the study area as the whole area was divided in to three (3) locations; each location was further sub-divided in to three (3) blocks to serve as a replicate. The Sampling areas were:

Sampling Area 1: This constituted the premises of Abdullahi Fodiyo Library Complex

Sampling Area 2: This comprised of Faculty of Education, Faculty of Agriculture (Annex), Department of Pure and Applied Chemistry and Premises of Energy Research Center of Usman Danfodiyo University, Sokoto.

Sampling Area 3: This extended from University premises down to Student hall of resident area.

\subsection{Assessment of Disease Incidence and Severity of Terminalia catappa}

The study area was surveyed; the trees were purposively selected from each block or replicate. Individual sampled trees were assessed by visual estimation method of diseases measurement.

The diseases incidence was determine by using the relation below as adopted by Charles and Amusa [10].

$$
\text { Disease incidence }(D I)=\frac{\text { No.of stand swith symptoms }}{\text { Total No. of stands assessed }} \times 100
$$

The diseases severity was determine using the diseases rating scale of 0-10 [11]. The severity was derived using the relation below

$$
\text { Disease Severity }(D S)=\frac{\text { Total No. ofdisease Ratings }}{\text { No. of Stands assessed } \times \text { Maximum scale }} \times 100
$$




\subsection{Sample Collection}

Diseased leaves picked from the infected trees were taken to the mycology laboratory of Department of Biological science in Botany unit of Usmanu Danfodiyo University Sokoto for the identification of the fungal pathogens responsible for the diseases.

\subsection{Laboratory Procedure for Identification of Diseases Causal Organism}

Materials used include: Petridish, cotton wool, foil paper, hand gloves, face mask, masking tape, microscope, cover slide, glass slide, $1000 \mathrm{ml}$ conical flask, autoclave, thermo or hot plate, weighing balance, hot air oven, PDA media (Potato Dextrose Agar), ethanol and an antibiotic (Streptomycin).

An amount of PDA media (39g) was dissolved in $1000 \mathrm{ml}$ of distilled water inside a conical flask as instructed by the manufacturer, $1 \mathrm{~g}$ of antibiotic (streptomycin) was added, cotton wool was used to seal the opening of the flask to make it air tight. The conical flask containing the media was subjected to a gentle heat on a thermo or hot plate until a homogenous or translucent suspension of the media was obtained. The resulting media was taken to an autoclave for sterilization at a temperature of $121^{\circ} \mathrm{C}$ for $15 \mathrm{~min}$.

Diseased leaves were sorted and taken to inoculation room and leveled A-D according to the symptoms obtained from the field. The diseases area or legion on the leaves was cleaned with cotton wool soaked inside ethanol to get rid of any pathogen that could have been present to avoid contamination. The diseased portion of the leaves were cut with scissors and plated at the center of Petridish containing the media. The plates were incubated in the growth room for $7 \mathrm{days}$ after which growth was observed. Sub culture was conducted to obtain a pure culture of the isolates.

\subsection{Identification of the fungal pathogen}

The organism was identified under a light microscope by placing a drop of distilled water on a glass after which an inoculation needle burned with Bunsen flame was used to pick small portion of the colony and dropped inside the water drop. The drop of water was covered by placing a cover slide at an angle of $45^{\circ}$ to eliminate the air bubbles that may impede the view. The glass slide covered with cover slide was fixed to clip of microscope and adjusted using different adjusters until the organism was clearly seen by switching between different lenses of the microscope. The organisms seen under the microscope were identified through the use of Cheesbrough [12] manual.

\subsection{Data analysis}

The data on incidence and severity was subjected to the analysis of variance (ANOVA) using Statistical Package for Social Sciences (SPSS).

\section{Results}

\subsection{Fungal diseases affecting the leaves of Terminalia catappa}

In the study conducted, it was discovered that the fungal diseases affecting the leaves of Terminalia catappa in the study area include the following;

\subsubsection{Aspergillus leaf spot}

The disease is caused by Aspergillus flavus. It is characterized by small, scattered, circular to oval dead areas on the leaves, usually tan dark brown. Some spots are raised and drop out leaving ragged holes; the spots are marked with light and dark concentric zones. Numerous spots developed reddish brown to black margins and later in damp weather, increase in size, number and merge in to angular to circular dead areas. Dark areas are speck- sized fungus fruiting bodies commonly formed in deadly tissues of many older spots. Heavily infected leaves turn yellow to brown, wither, and drop early, weakening the tree.

\subsubsection{Aspergillus leaf blight}

The symptoms on leaves begin with solid reddish brown spot that develop a tan center as they grow. As the diseases progress, the spot enlarge to V-shaped legions with dry brown centers and reddish purple boarders. Severe infection turns a whole leaflet brown. Fungal spores producing structures appear as black specks that dot central area of the legion. 


\subsubsection{Black Mould Disease}

The black mould or spot diseases of ornamental species is caused by Aspergillus niger. Small yellow spot occur on the upper leaf surface, as the spots increases in size they turn black. The spots usually appear as single dark areas, but may occur as a local concentration of many small spots. Infected leaves are held on the tree until normal leaf drop.

\subsubsection{Powdery Mildew}

The symptoms on foliage develops patches of gray- white materials which resembles powder or dust on top of the leaves, in some cases, a white" powder" or dust on top of the leaves may be dislodge during handling. The patches are must abundant on leaves in the lower branches and in heavily shaded branches. Heavily infected foliage are discolored, distorted, or stunted but light to moderate infected leaves appear otherwise normal. The fungal pathogen responsible for the diseases are obligate parasites, as such they can't be cultured on artificial medium.

\subsection{Incidence and Severity of Terminalia catappa in the Study Area}

\subsubsection{Incidence and Severity of Aspergillus leaf spot of Terminalia catappa}

The incidence and severity of Aspergillus Leaf Spot of Terminalia catappa is presented in Table 1, with significant difference among the treatments. The differences were limited to disease severity, as no any statistically significant difference was observed in the diseases incidence, however, Location 2 lead the incidence list with (100\%), followed by Location 1 with (96.97\%). The least diseases incidence value was recorded in Location 3with (69.84\%).

On the other hand, Location 2 topped the severity list with (62.20\%) which is statistically similar to Location 1 with $(53.17 \%)$ in terms of diseases severity. The least diseases severity value was recorded in location 3with (15.87\%)

Table 1 Incidence and Severity of Aspergillus leaf spot of Terminalia catappa

\begin{tabular}{lll}
\hline Locations & Incidence (\%) & Severity (\%) \\
\hline 1 & $96.67 \pm 5.25 \mathrm{a}$ & $53.17 \pm 14.84 \mathrm{a}$ \\
2 & $100 \pm 0.00 \mathrm{a}$ & $62.60 \pm 10.45 \mathrm{a}$ \\
3 & $69.84 \pm 28.70 \mathrm{a}$ & $15.87 \pm 8.85 \mathrm{~b}$ \\
Standard Error & 6.83 & 7.84 \\
Level of Significance & Ns & $*$ \\
\hline
\end{tabular}

Means followed by the same letter(s) do not differ significantly according to Duncan's Multiple Range Test (DMRT) at 5\% level of significance

\subsubsection{Incidence and Severity of Aspergillus Blight of Terminalia catappa}

The incidence and severity of Aspergillus Blight of Terminalia catappa is presented in table 2, showing significant difference among the treatments with regards to diseases incidence. Location 2 recorded the highest incidence of (95.24\%) which is statistically similar to Location 1with (78.55\%). Although, no statistically significant difference exist between Location 1 and Location 3the later has the least cases of the diseases with (53.97\%).

Severity index shows no significant difference among the treatment, but Location 1has the highest value of (12.65\%), followed by Location 2 with (11.14\%) and the least was found in Location 3 with $(7.30 \%)$.

Table 2 Incidence and Severity of Aspergillus Blight of Terminalia catappa

\begin{tabular}{lll}
\hline Locations & Incidence (\%) & Severity (\%) \\
\hline 1 & $78.55 \pm 21.39 \mathrm{ab}$ & $12.65 \pm 8.16 \mathrm{a}$ \\
2 & $95.24 \pm 8.25 \mathrm{a}$ & $11.14 \pm 1.03 \mathrm{a}$ \\
3 & $53.97 \pm 19.25 \mathrm{~b}$ & $7.30 \pm 3.51 \mathrm{a}$ \\
Standard Error & 7.8 & 1.69 \\
Level of Significance & $*$ & Ns \\
\hline
\end{tabular}

Means followed by the same letter(s) do not differ significantly according to Duncan's Multiple Range Test (DMRT) at 5\% level of significance 


\subsubsection{Incidence and Severity of Black Mould Diseases of Terminalia catappa}

The incidence and severity of Black Mould Diseases of Terminalia catappa is presented in table 3 with no significant difference among the treatments with regards to both indices of diseases intensity. The highest diseases incidence value was recorded in Location 2 as $(94.90 \%)$, followed by Location 1with $(73.89 \%)$ and the least value was recorded in Location 3as (59.52\%). On the other hand, Location 2topped the severity list with (16.86\%), followed by Location 1 with $(14.27 \%)$ and the least was Location 3 with $(13.36 \%)$.

Table 3 Incidence and Severity of Black Mould Disease of Terminalia catappa

\begin{tabular}{lll}
\hline Locations & Incidence (\%) & Severity (\%) \\
\hline 1 & $73.89 \pm 36.62 \mathrm{a}$ & $14.27 \pm 9.98 \mathrm{a}$ \\
2 & $94.90 \pm 8.83 \mathrm{a}$ & $16.86 \pm 5.52 \mathrm{a}$ \\
3 & $59.52 \pm 10.91 \mathrm{a}$ & $13.36 \pm 6.92 \mathrm{a}$ \\
Standard Error & 8.44 & 2.31 \\
Level of Significance & Ns & Ns
\end{tabular}

Means followed by the same letter(s) do not differ significantly according to Duncan's Multiple Range Test (DMRT) at 5\% level of significance

\subsubsection{Incidence and severity of Powdery Mildew of Terminalia catappa}

The result of the incidence and severity of powdery mildew of Terminalia catappa is presented in table 4, with significant difference among treatments with regards to the diseases intensity index. Location 2lead the diseases incidence with (85.71\%), however, it is statistically similar to Location 1with $(53.38 \%)$, the least incidence value was obtained in Location 3with only (15.08\%).

With regards to diseases severity, no significant difference between Location 1and Location 3with (9.65\%) and (3.89\%) respectively, the highest diseases severity value was recorded in Location 2 with (34.0\%).

Table 4 Incidence and Severity of Powdery Mildew of Terminalia catappa

\begin{tabular}{lll}
\hline Locations & Incidence (\%) & Severity (\%) \\
\hline 1 & $53.58 \pm 16.47 \mathrm{a}$ & $9.65 \pm 3.73 \mathrm{~b}$ \\
2 & $85.71 \pm 24.76 \mathrm{a}$ & $34.0 \pm 15.99 \mathrm{a}$ \\
3 & $15.08 \pm 14.35 \mathrm{~b}$ & $3.89 \pm 5.36 \mathrm{~b}$ \\
Standard Error & 11.6 & 5.44 \\
Level of Significance & $*$ & $*$ \\
\hline
\end{tabular}

Means followed by the same letter(s) do not differ significantly according to Duncan's Multiple Range Test (DMRT) at $5 \%$ level of significance

\section{Discussion}

Aspergillus leaf spot is characterized by small, circular, scattered, circular to oval dead areas usually tan to dark brown. This agrees with the findings of Zhang et al. [13], that Aspergillus leaf spot infect the leaves of bind weed (Convolvulus curvensis $\mathrm{L}$ ); The diseases developed a circular to irregular, small to medium dark brown spot with conspicuous margin. Some spot dropped out leaving ragged holes on the leaves. In severe infection there was premature yellowing and casting of leaves. Fungus fruiting bodies developed on the center of the older spot. From the result, this disease is caused Aspergillus flavus which was described by [14] as a saprotrophic and pathogenic.

Aspergillus Blight starts with the solid reddish brown spot that develop tan center as they grow. The brown spots have reddish purple boarders. This goes in line with the work of Ghose [15]. They reported that leaf blight on the leaf of mulberry starts with small to large, circular to irregular dark brown spots; some spots were purplish brown and appeared often along the margin and veins. Spots have yellow to dark brown margin and the leaves are distorted.

In Black Mould Disease, the symptom shows small, yellow spot on the abaxial surface of the leaves. It increases in size as they turn black. This agrees with the work of Angel [16], that the disease developed a yellow, oval to irregular spots 
that later latter became, coal black, thickened, raised and wrinkle on the leaves of black mangrove. The result is also in support of the work of Sneh [17] as they declared Black mould as a very serious diseases that affect plant in general and vegetables in particular. It is also known to cause stem rot of Dracaena [18]; root stalk of Sasavieria; and boll rot of cotton; spoilage of cashew kernels, date, figs, vanilla pods and dried prune [19].

Powdery mildew develops patches of gray -white materials which resemble powder or dust on top of the foliage. This agrees with the findings of Urbanietez and Dunemann [20] on Apple that the disease appeared as white powder-like patches on the surface of the leaves, the disease developed most on the newer leaves. It also appeared as blotchy, felt like mat or cobweb like formation. The disease increase when cooler weather paired with high humidity and the sign occurred more frequently in areas of tree that are shaded and lack good air flow. As the disease spreads, the leaves begin to yellow and wilt. The advanced symptoms showed leaf distortion and premature leaf drop.

\subsection{Incidence and Severity of Fungal Diseases of Terminalia catappa}

The result of incidence and severity shown in Table 1, 2, 3 and 4 showed almost similar trend as the diseases incidence exceed diseases severity in all cases. Location 2 appeared to experience the highest incidence with respect to all the four (4) different diseases identified in the study area. This coincides with the findings of Payne [21] that Aspergillus spp. Which found to be the causative agent for Aspergillus leaf spot, Aspergillus blight, and Black mould diseases thrive very well in hot and harsh weather condition. This also coincides with the stress period of the trees in dry season when they are probably weak and more susceptible [22; 23]. It might also be due to the fact that Location 2 comprises of areas that are more or less closed with crowded trees that creates suitable microclimate to fungal pathogen as opposed to Location 3 with very spares distribution of trees, hence these areas recorded the least intensity of all the diseases. Powdery mildew however, showed the highest severity value in Location 2 . This goes in line with the findings of Urbanietez and Dunemann [20], that the disease increases when cooler weather is paired with high humidity.

\section{Conclusion}

At the termination of this study, the results revealed that fungal diseases attack the leaves of Terminalia catappa and Aspergillus spp of fungi are responsible for this infection in three (3) out of four diseases identified, however powdery mildew which are caused by obligate parasite fungus are also present in the area. Areas with crowded trees and closed canopy are the most severely affected with respect to all the diseases.

Considering the findings from this study, the following recommendations are here by proposed.

- Ensuring good air circulation will help to keep the foliage dry and make it unfavorable to pathogens

- Infected leaves, dead twigs, should be removed through ranking and other sanitary practices to limit the infection and reduce the total number of inoculums.

\section{Compliance with ethical standards}

\section{Acknowledgments}

We acknowledge the contribution of Technologists in the Mycology Laboratory, Usmanu Danfodiyo University Sokoto, Nigeria.

\section{Disclosure of conflict of interest}

We wish to declare that, there was no conflicting interest

\section{References}

[1] Exell AW. (1954) Combretaceae. In: Flora Malesiana, 14 (5), 533-589.

[2] Coode MJE. (1978). Combretaceae. In: Womersley JS, (eds), Handbooks of the flora of Papua New Guinea, 1. Melbourne, Australia; Melbourne University Press.

[3] Smith AC. (1985). Flora Vitiensis nova: a new flora of Fiji (Spermatophytes only). Angiospermae: Dicotyledones, families, 3, 117-163. 
[4] Wheatley JI. (1992). A guide to the common trees of Vanuatu with lists of their traditional uses \&ni-Vanuatu names, 308.

[5] Heinsleigh TE and Holaway BK. (1988). Agroforestry species for the Philippines. Metro Manila Philippines: US Peace Corps, AJA Printers.

[6] Douglas SM. (2012). Leaf spot diseases of ornamental trees and shrubs, The Connecticut Experiment station report.

[7] Bello AG. (2002). Evaluation of Parkia biglobosa (jacq) R. BR Ex. G. Don. Based Agroforestry System in Sudan savanna Zone of Nigeria. A PhD. Thesis submitted to the post graduate school Usmanu Danfodiyo University Sokoto Nigeria (Unpublshed), 142.

[8] Anonymous. (2014). 'Sokoto State".

[9] Ojo O. (1991). Overcoming Hunger: The Challenges in Meteorological Hazards and Agricultural Development. In Oguntoyinbo, J.S., Omotosho, J.B. and Ekuwem, E.E. (Eds.) Meteorological Hazards and Development, Lagos, Kola Okanlawon Publisher, 22-36.

[10] Charles AO and Amusa NA. (2015). Incidence and Severity of Anthracnose in Mango Fruits and its Control with Plant Extracts in South West Nigeria. International Journal of Agricultural Research, 10, 33-43.

[11] Horsfall JG and Cowling EB. (1978). phytometry: The measurement of plant diseases. In: Kranz J. Rotem J. (eds) Plant diseases. Vol 11. How diseases develop in a population. Academic press, New York, 119-136.

[12] Zhang XX, Hiu Z, Liu Y, Yu Y Sun and J Zhao. (2016). Aspergillus Leaf Spot of field bind weed (Convolvulus arvensis L.) caused by Aspergillus spp. In China Springer plus, 5, 605.

[13] Machida M and Gomi MK. (2010). Aspergillus: Molecular Biology and Genomics. Horizon Scientific Press, 157.

[14] Ghose L, FA Neela, TC Chakaravorty, MR Ali and MS Alam. (2010). Incidence of leaf blight of Mulberry plant and assessment of changes in amino acid and photosynthetic pigments of infected leaf. Pathology journal, 9, 140-143.

[15] Angel MN, Tattar TA and Williams EH. (2012). Sooty mould on leaves of black mangrove in Arboricultural Journal, 26(2), 141-155.

[16] Sneh A, F Accensi and J Cano. (1991). Production of aflatoxins by Aspergillus flavus and Aspergillus niger strains isolated from seeds of pulses. Journal of Food Agriculture and Environment, 7, 33-39.

[17] Abbasi M and F Aliabadi. (2008). First report of stem rots of Dracaena caused by Aspergillus niger in Iran. Plant Health Progress.

[18] Bobbarala VP, K Katikala, KC Naidu and S Penumajji. (2009). Antifungal activity of selected plants extracts against phytopathogenic fungi Aspergillus niger. Indian Journal of Science and Technology, 20, 87-90.

[19] Urbanietez A and F Dunemann. (2005). Isolation and Identification and Molecular characterization of physiological races of Apple Powdery mildew. Plant pathology, 54, 125-133.

[20] Payne GA. (1999). Aspergillus Ear Rot In:Donald G.White(ed). Compendium of Corn Disease. St. Paul. Minnesota. The American Physiological Society, 44.

[21] Salau IA, Shehu K, Muhammad S and Umar RA. (2017). Aflatoxin Contamination of Stored Groundnut Kernel in Sokoto State, Nigeria. Greener Journal of Agricultural Sciences, 6(10), 285-293.

[22] Salau IA, K Shehu and AA Farouq. (2017). Molecular Characterization of Mycotoxin Producing Fungi Contaminating Groundnut Products In Sokoto State, Nigeria. J. of Computation in Biosciences and Engineering, $3(4), 1-4$.

\section{How to cite this article}

Nasiru AM, Sarki MA and Dalhatu MH. (2020). A survey on fungal foliar diseases of Terminalia catappa in Usmanu Danfodiyo University Sokoto Northwestern Nigeria. World Journal of Advanced Research and Reviews, 6(3), 142-148. 